\title{
CUSTOMER SATISFACTION ASSESSED FROM LIFESTYLE, PROMOTION, AND QUALITY
}

\author{
Indah Kumalasari*1, Bambang Mursito² \\ Universitas Islam Batik, Indonesia*12 \\ kumalaindah67@gmail.com ${ }^{* 1}$, bambangmursito1959@gmail.com²
}

\begin{abstract}
Customer Satisfaction in terms of Shopee's Lifestyle, Promotion, and Service Quality. Thesis, Department of Management, Faculty of Economics, Islamic University of Batik Surakarta, 2021. This study aims to prove the simultaneous and partial effect of Customer Satisfaction in terms of Lifestyle, Promotion, and Shopee E-Commerce Service Quality. This research is quantitative descriptive. The population is all Shopee E-commerce buyers. The number of samples used by Sugiyono's guidelines, amounting to 100 respondents, the sample was taken by purposive sampling technique. The data analysis technique used in this study was multiple linear regression analysis. The results of the study indicate that the F-test of lifestyle, promotion, and service quality simultaneously and significantly affects Shopee e-commerce customer satisfaction. The t-test results show that lifestyle has a positive and significant effect on customer satisfaction of Shopee's e-commerce, the promotion has a positive and significant effect on Shopee e-commerce customer satisfaction, service quality has a positive and significant effect on Shopee e-commerce customer satisfaction. The coefficient of determination shows that lifestyle, promotion, and service quality variables on Shopee e-commerce customer satisfaction. The most dominant influence on Shopee ecommerce customer satisfaction is lifestyle variables because it has the largest.
\end{abstract}

Keywords: Customer Satisfaction; Lifestyle; Promotion; Service Quality

\section{INTRODUCTION}

Nowadays online shopping is a choice. Customers and sellers are not bothered by meeting in person, like traditional markets in general. Online shopping is a place where sellers and buyers meet online or through applications on gadgets. Transactions can not only be made within one country but also between countries. The convenience that online shopping applications offer for buyers is the ease of transactions, various products are available with complete descriptions, a wide range of delivery of goods accessed through various media, and promos available. The development of technology is so fast, in line with the increase in transactions in electronic commerce (e-commerce) in Indonesia.

People who have many market competitors, agriculture want to survive and develop rapidly, companies must continually innovate and develop up-to-date market strategies, hone so that they are not left behind with other market technologies. Satisfaction is an individual expression that describes feelings of pleasure and regret after receiving a product or service, based on a comparison of expectations before buying and reality after receiving goods or services (Januar, 2016).

Customer satisfaction can be increased through several factors, including companies that study consumer lifestyles, carry out promotions, and improve service quality. Lifestyle is a measuring tool for consumers to make purchasing decisions, this will have an impact on customer satisfaction. Customer satisfaction is based on the performance of a product. The lifestyle of each person and society is different. Customer perspective with a lifestyle based on interest (interest) in using his time and money. Different lifestyles will result in variations in the creativity and creativity of the items presented. The lifestyle of each community group is different, starting from the bottom, middle and top. 
Shopee seeks to understand people's needs through lifestyle variables through collaboration with online shops, SMEs to well-known product manufacturers to meet customers' needs and lifestyles. Lifestyle facilitates consumer choice through the influence of the surrounding environment both individually and in groups. Lifestyle provides choices in making purchases and if following expectations the buyer will be satisfied with what he does. Shopee is a digital shopping platform that is actively promoting. Promotion is carried out through social media, Instagram, Twitter, youtube, and television media, in the form of free shipping discounts, discounted prices with a minimum purchase of goods or prices, and flash sale offers, through television advertisements, sponsorship of events, and the presentation of attractive features which prove to be attractive. customer interest. The promotions carried out by Shopee are not only limited to promos and advertisements, Shopee collaborates with many K-pop artists, celebrities, and Indonesian artists to busy offering people to shop using Shopee. Promotion is the business of providing a service or company to provide information to the public and the market regarding the products offered, the place and time they take effect (Tjahjaningsih, 2013).

Shopee is a digital shopping platform that is actively promoting. Promotion is carried out through social media, Instagram, Twitter, youtube, and television media, in the form of free shipping discounts, discounted prices with a minimum purchase of goods or prices, and flash sale offers, through television advertisements, sponsorship of events, and presentation of attractive features which prove to be attractive. customer interest. The promotions carried out by Shopee are not only limited to promos and advertisements, Shopee has collaborated with many K-pop artists, celebrities, and Indonesian artists to busy offering the community to shop using Shopee.

Service quality is an effort to fulfill consumer wants and expectations, fulfillment of these expectations can also be realized through delivery to balance consumer expectations. Service quality as a measure of customer satisfaction. Quality is a description of the consistency that a company does in maintaining its bonds with customers. The services offered at Shopee e-commerce are following the needs of the community, including 24-hour chat services, money and goods refund handlers in the event of a mismatch between sellers and buyers, and providing suggestion boxes for consumers who have complaints.

Customer Satisfaction is a description of the feelings felt by buyers who buy and receive goods, based on a comparison of expectations and desires to buy with reality and reality after receiving goods or services (Januar, 2016). Lifestyle is a human habit of using free time through activities that they think should be done and thought about them and the environment (Amstrong, 2014) Lifestyle briefly contains the meaning of activities, interests, and opinions. Lifestyle is a measuring tool for consumers to make purchasing decisions, this will have an impact on customer satisfaction. Customer satisfaction is obtained based on the performance of a product. Promotion is a means owned by producers to introduce their products to the public through the value and innovation of the products they produce. The promotion aims to provide product introduction, explanation of specifications which aim to lure consumers to have the desire to buy an item (Sagita, 2013)

Service quality is an effort to fulfill the desires and expectations of consumers, fulfillment of these expectations can also be realized through delivery to balance consumer expectations (Januar, 2016). Service quality as a measure of customer satisfaction. Quality is a description of the consistency that a company does in maintaining its bonds with customers. The purpose of this study is as follows is to determine and analyze the influence of lifestyle on customer satisfaction of E-Commerce Shopee. To find out and analyze the effect of promotions on customer satisfaction E- 
Commerce Shopee. To find out and analyze the effect of service quality on customer satisfaction E-Commerce Shopee.

\section{METHODS}

This research method is quantitative through a descriptive approach. Conducted from September 2020 to January 2021 in the City of Surakarta. A population is a person who generally has an attachment to the research taken. Populations are people, objects, and other objects that are useful in a study. The population of this research is Shopee E-commerce users. The sampling technique of this research is judgmental, so it is obtained 100 respondents from Shopee E-commerce users.

\section{RESULTS AND DISCUSSION}

Table 1. Validity Test Results

\begin{tabular}{lccc}
\hline \multicolumn{1}{c}{ Statement } & r count & r Table & Information \\
\hline Customer Satisfaction (Y) & 0,794 & 0,3739 & Valid \\
Statement 1 & 0,678 & 0,3739 & Valid \\
Statement 2 & 0,734 & 0,3739 & Valid \\
Statement 3 & 0,891 & 0,3739 & Valid \\
Statement 4 & 0,909 & 0,3739 & Valid \\
Statement 5 & & & \\
Lifestyle $(X 1)$ & 0,788 & 0,3739 & Valid \\
Statement 1 & 0,760 & 0,3739 & Valid \\
Statement 2 & 0,733 & 0,3739 & Valid \\
Statement 3 & 0,807 & 0,3739 & Valid \\
Statement 4 & 0,722 & 0,3739 & Valid \\
Statement 5 & 0,665 & 0,3739 & Valid \\
Statement 6 & & & \\
Promotion (X2) & 0,851 & 0,3739 & Valid \\
Statement 1 & 0,712 & 0,3739 & Valid \\
Statement 2 & 0,787 & 0,3739 & Valid \\
Statement 3 & 0,863 & 0,3739 & Valid \\
Statement 4 & 0,834 & 0,3739 & Valid \\
Statement 5 & 0,804 & 0,3739 & Valid \\
Statement 6 & & & \\
Quality of Service (X3) & 0,620 & 0,3739 & Valid \\
Statement 1 & 0,762 & 0,3739 & Valid \\
Statement 2 & 0,901 & 0,3739 & Valid \\
Statement 3 & 0,866 & 0,3739 & Valid \\
Statement 4 & 0,781 & 0,3739 & Valid \\
Statement 5 & & & \\
\hline
\end{tabular}

Source: Primary data processed (2020)

In conclusion, 22 statements were presented by 30 respondents with a minimum validity index value of 0.3739 , so all statements can be used as a questionnaire.

Table 2. Reliability Test Results

\begin{tabular}{lccc}
\hline \multicolumn{1}{c}{ Variable } & Cronbach Alpha & Nunnally criteria & Information \\
\hline Customer satisfaction & 0,808 & 0,600 & Reliable \\
Lifestyle & 0,787 & 0,600 & Reliable \\
Promotion & 0,796 & 0,600 & Reliable \\
Service quality & 0,804 & 0,600 & Reliable \\
\hline
\end{tabular}

Source: Primary data processed (2020) 
The reliability test can be done using the SPPS version 22 program by selecting the Analyze menu, then selecting a scale, then selecting Reliability Analysis. The results of the analysis were obtained through Cronbach Alpha and reliability test results based on the results of the validity test above, it can be concluded that all statements submitted are reliable.

Table 3. Results of Multiple Linear Regression Testing

\begin{tabular}{lccc}
\hline \multicolumn{1}{c}{ Variable } & B & $\mathbf{T}_{\text {count }}$ & Sig \\
\hline Constant & 0,204 & 0,188 & 0,851 \\
Lifestyle & 0,404 & 6,477 & 0,000 \\
Promotion & 0,288 & 4,588 & 0,000 \\
Service quality & 0,213 & 3,039 & 0,003 \\
$\mathrm{R}_{2} \quad: 0,880$ & & $\mathrm{~F}_{\text {count }}: 109,545$ & \\
Adjusted $\mathrm{R}_{2}: 0,767$ & & $\mathrm{~F}_{\text {sig }}: 0,000$ & \\
\hline
\end{tabular}

$$
\begin{aligned}
& \text { Source: Primary data processed (2020) } \\
& \mathbf{Y}=\mathbf{0}, \mathbf{0 2 4 + 0 , 4 0 4 X 1 + 0 , 2 8 8 X 2 + 0 , 2 1 3 X 3 + e}
\end{aligned}
$$

The constant value for the regression equation is 0.024 . The regression coefficient on the trust independent variable is positive at 0.404 . The regression coefficient on the security independent variable is positive at 0.288 . The regression coefficient on the independent variable of information quality is positive at 0.213 .

Table 4. Results of the Determination Coefficient Test

\begin{tabular}{cccc}
\hline Model & $\mathbf{R}$ & R Square & Adjusted R Square \\
\hline 1 & 0,880 & 0,774 & 0,767 \\
\hline & Source: Primary data processed (2020)
\end{tabular}

Based on the above analysis, it is obtained R2 0.767 or $76.7 \%$. X1, X2, X3 76.7\% effect on $\mathrm{Y}$. The rest is influenced by other variables outside this study.

Table 5. F-Test Results

\begin{tabular}{ccccccc}
\hline Model & Sum Of Squares & DF & Mean Square & F & Sig & Information \\
\hline Regression & 524,906 & 3 & 174,969 & 109,545 & 0,000 & Signifikan \\
Residual & 153,334 & 96 & 1,587 & & & \\
Total & 678,240 & 99 & & & \\
\hline \multicolumn{7}{c}{ Source: Primary data processed (2020) }
\end{tabular}

Based on the table, the results of the $F$ test show that the value of $F_{\text {count }}$ is $109.545>$ Ftable which is 2.70 with a significance of 0.000 , which means $<0.05$. From this value, it can be concluded that the variables $\mathrm{X} 1, \mathrm{X} 2, \mathrm{X} 3$ simultaneously have a significant effect on variable $\mathrm{Y}$.

Table 6. T-Test Results

\begin{tabular}{lcccl}
\hline \multicolumn{1}{c}{ Variable } & $\mathbf{T}_{\text {table }}$ & $\mathbf{T}_{\text {count }}$ & Sig. & Information \\
\hline Lifestyle & 6,477 & 1,984 & 0,000 & Ho rejected \\
Promotion & 4,588 & 1,984 & 0,000 & Ho rejected \\
Service quality & 3,039 & 1,984 & 0,003 & Ho rejected \\
\hline \multicolumn{4}{c}{ Source: Primary data processed $(2020)$} &
\end{tabular}


Based on the results of the t-test table above, it can be explained as follows:

It is known that the lifestyle variable (X1) shows the value of $t_{\text {count }}(1.984)>t$ table (6.477) and $t_{\text {sig }}(0.000)$ smaller than $\alpha(0.05)$, it can be concluded that lifestyle variables have a positive and significant effect on customer satisfaction E-commerce Shopee. It is known that the promotion variable (X2) shows the value of $t_{\text {count }}(1.984)>t$ table (4.588) and $t_{\text {sig }}(0.000)$ smaller than $\alpha(0.05)$, it can be concluded that the promotion variable has a positive and significant effect on customer satisfaction of E-commerce Shopee. It is known that the service quality variable $(X 3)$ shows the value of $t_{\text {count }}(1.984)>t$ table (3.039) and $t_{\text {sig }}(0.003)$ smaller than $\alpha(0.05)$, so it can be concluded that the promotion variable has a positive and significant effect on customer satisfaction E-commerce Shopee.

The pattern of life that is carried out by a person is manifested through activities, desires, and expenses in spending and income when allocating time (Nugroho, 2010). Lifestyle is a measuring tool for consumers to make purchasing decisions, this will have an impact on customer satisfaction. Customer satisfaction is obtained based on the performance of a product. The lifestyle of each person and society is different. Customer perspective with a lifestyle based on interest (interest) in using his time and money. Different lifestyles will result in variations in the thinking and creativity of the items presented. The results showed that "lifestyle affects customer satisfaction", with the reason that a high lifestyle can increase customer expectations and satisfaction of an item.

The business of providing a service or company to provide information to the public and the market regarding the products offered, the place, and the time they take effect is part of the promotion (Tjahjaningsih, 2013). Shopee is a digital shopping platform that is actively promoting. Promotion is carried out through social media, Instagram, Twitter, youtube, and television media, in the form of free shipping discounts, discounted prices with a minimum purchase of goods or prices, and flash sale offers, through television advertisements, sponsorship of events, and presentation of attractive features which prove to be attractive. customer interest. The promotions carried out by Shopee are not only limited to promos and advertisements, Shopee has collaborated with many K-pop artists, celebrities, and Indonesian artists to busy offering the community to shop using Shopee. The results of the study show that "the promotion variable has a significant effect on customer satisfaction". The reason is that promotional activities have a period and the goal is to stimulate consumer purchases, high promotional intensity can increase people's buying interest, if the offeror promotion is following the condition of the goods, the customer will be satisfied.

Efforts to fulfill consumer wants and expectations, the fulfillment of these expectations can also be realized through delivery to balance consumer expectations. Service quality as a measure of customer satisfaction. Quality is a description of the consistency that a company does in maintaining its bonds with customers. The services offered at Shopee e-commerce are following the needs of the community, including 24hour chat services, money and goods refund handlers in the event of a mismatch between sellers and buyers, and providing suggestion boxes for consumers who have complaints. The result "service quality affects customer satisfaction". The reason is that quality service can provide positive energy for customers and can increase satisfaction.

\section{CONCLUSION}

The results of the $\mathrm{F}$ test show that the variables of lifestyle, promotion, and service quality simultaneously and significantly have a positive effect on customer satisfaction at Shopee. The t-test results show that: Lifestyle variables have a positive and significant effect on customer satisfaction at Shopee. This shows that the higher the lifestyle, the 
purchasing decisions will also increase. Promotion variables have a positive and significant effect on customer satisfaction at Shopee. Promotional activities have a time and the goal is to stimulate consumer purchases, the higher the promotion, the higher the customer satisfaction. service quality variables have a positive and significant effect on purchasing decisions at Shopee. the better the quality of service provided, the more customer satisfaction will increase.

\section{REFERENCES}

Amstrong, \& K. (2014). Prinsip- Prinsip Pemasaran. Jakarta: Erlangga.

Januar, \& A. L. (2016). Pengaruh Kualitas Pelayanan terhadap Kepuasan Pelanggan Pada JNE Cabang Bandung. DeReMa Jurnal Manajemen.

Nugroho, S. (2010). Perilaku konsumen: perspektif Kontemporer pada Motif, Tujuan, dan Keinginan Konsumen. Jakarta: Kencana Prenada Media.

Sagita. (2013). Pengaruh Brand Image dan Harga terhadap Keputusan Pembelian Ulang Produk Kentucky Fried Chicken (KFC) di Cabang Basko Grand Mall. Universitas Negeri Padang.

Tjahjaningsih, Endang. (2013). Pengaruh Citra dan Promosi terhadap Kepuasan Pelanggan Serta Dampaknya Terhadap Loyalitas Pelanggan. Media Ekonomi Dan Manajemen, 28. 